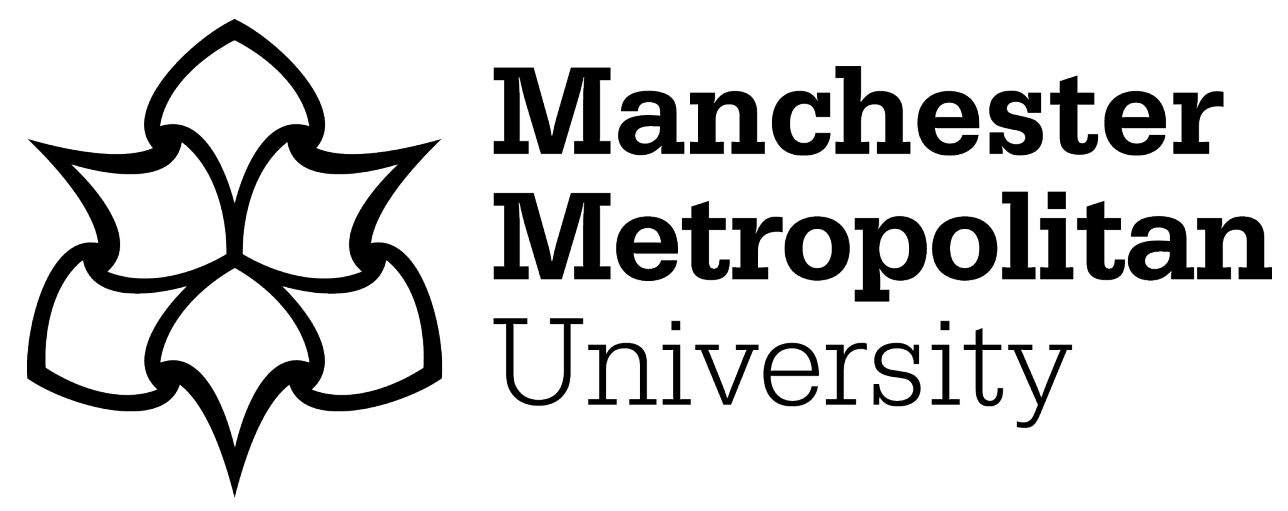

Wilkinson, C, Silverio, SA and Wilkinson, S ORCID logoORCID: https://orcid.org/0000-0002-1564-5472 (2020) The neoliberal university and the neurotic academic: A textual analysis of ITV drama Cheat. Journal of Further and Higher Education, 45 (2). pp. 257-269. ISSN 0309-877X

Downloaded from: https://e-space.mmu.ac.uk/628652/

Version: Accepted Version

Publisher: Taylor \& Francis

DOI: https://doi.org/10.1080/0309877X.2020.1751093

Usage rights: Creative Commons: Attribution-Noncommercial 4.0

Please cite the published version 


\title{
The neoliberal university and the neurotic academic: A textual analysis of ITV drama Cheat
}

\author{
Catherine Wilkinson (1D) ${ }^{\text {a }}$, Sergio A. Silverio $\mathbb{( D D}^{\mathrm{b}, \mathrm{c}, \mathrm{d}}$ and Samantha Wilkinson $\left(\mathbb{D}^{\mathrm{e}}\right.$ \\ aSchool of Education, Liverpool John Moores University, Liverpool, UK; 'Department of Women \& Children's Health, \\ King's College London, London, UK; 'EGA Institute for Women's Health, University College London, London, UK;

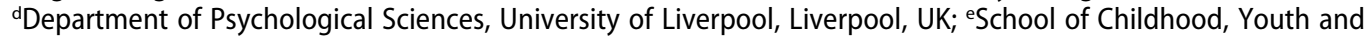 \\ Education Studies, Manchester Metropolitan University, Manchester, UK
}

\begin{abstract}
Through a textual analysis of four episodes comprising the ITV 1 psychological thriller Cheat, this paper explores depictions of the English Higher Education [HE] landscape and of the lived experiences of being an academic in the television drama. We achieve this through a focus on the fictional HE institution where the drama is set - St. Helen's College - and the central character, university Lecturer: Dr Leah Dale; who is employed on a fixed-term contract and is applying for tenure. This paper engages with the following themes: Emotional Labour; Precarity of Fixed-Term Contracts; and Imposter Syndrome. Insight gleaned through the textual analysis contributes to the understanding of how academics might be navigating and negotiating the neoliberal university. In particular, we highlight the implications of contractual precarity in $\mathrm{HE}$ and the fragility of identity which is experienced by some academics. As such, this paper goes some way towards remedying the deficit of scholarship on the lived experiences of being a contemporary academic.
\end{abstract}

\section{ARTICLE HISTORY}

Received 8 November 2019

Accepted 30 March 2020

\section{KEYWORDS}

Emotional labour; contractual precarity; fixedterm contracts; imposter syndrome; neoliberal university; television; textual analysis

\section{Introduction}

The Higher Education [HE] environment has undergone seismic shifts in the last 50 years (Bruce 2012). More changes are expected in English HE as the Government's HE White Paper: Success as a Knowledge Economy: Teaching Excellence, Social Mobility and Student Choice, redraws relationships between government, students, and research (Boxall 2016). Through a textual analysis of four episodes comprising the ITV1 psychological thriller Cheat, this paper explores depictions of the current HE Landscape in England and of the lived experiences of being an academic, as portrayed in a television drama.

Cheat was broadcast on ITV 1 over four consecutive nights in March 2019. At the heart of the series is the toxic relationship between fixed-term university Lecturer: Dr Leah Dale, and the finalyear undergraduate student: Rose Vaughan; at St. Helen's College, a fictional HE institution, though filmed in Cambridge, England, on the grounds of the prestigious University of Cambridge. The series begins poignantly, with Leah delivering a lecture to students on power and coercion. We quickly see the interaction between Leah and Rose as the latter is called into the former's office to discuss a case of academic fraud. Leah tells Rose that her dissertation feels 'different' to her previous essays submitted in terms of content and style and asks Rose if she 'had some help' in producing her dissertation. Rose quickly interprets this as an accusation of cheating. The series proceeds to track the relationship between lecturer and student as well as their families, blurring the lines between 
private and public spheres, before moving into a 'whodunit' type murder mystery - the fatality being Leah's husband. Whilst the relationship between Leah and Rose is compelling and certainly deserving of academic inquiry, in this paper we focus on Leah, and her role as an academic navigating and negotiating the so-called neoliberal university, that is the university as a market-driven system which employs modes of governance based on a corporate model (Enright, Alfrey, and Rynne 2017).

Though different in context and time, the last major serious (i.e. not comedy) work of film to focus on HE in the England was - to the authors' knowledge - the 1983 film: Educating Rita (Gilbert 1983), where a working-class Liverpudlian mature student (Rita) is assigned to an Open University supervisor (Dr Frank Bryant - a long-time drunkard). During the film, the two central characters develop a close and complex relationship as they both struggle with imposter-like feelings - Rita amongst the younger, middle-class students, and Frank as a jaded academic unable to fulfil his wish to be a poet (for an academic analysis of working-class women as academics see Fraser et al. 2016).

Whilst it has been reported that there is 'a striking dearth of work' (scholarship) on academic labour and the effects of the changes occurring in HE on academic staff (Baron 2014; Gill 2014, 12) there are notable recent exceptions. For instance, Enright, Alfrey, and Rynne (2017) write on becoming an academic in the neoliberal university; and Loveday (2018a) discusses the idea of neurotic academics and modern university governance. Other scholars have published widely on $\mathrm{HE}$, for instance, Barcan $(2013,2018,2019)$ on the temporalities of academic careers, and Connell (2015a, 2015b, 2019) on academic labour and universities' functionality. There is, however, a relative absence of the HE environment in television documentaries, films and dramas. Cheat therefore provides us with a rare opportunity to explore the current HE landscape, and how academics might be navigating and negotiating this in an English university setting, and to contribute to this burgeoning body of literature.

This paper proceeds as follows. First, we provide an overview of the changed and changing English HE landscape. We then outline our approach to the textual analysis of Cheat. In the substantive analytical section of this paper, we present findings around the themes of: Emotional Labour; Precarity of Fixed-Term Contracts; and Imposter Syndrome. After a discussion of our findings, we conclude by arguing that insight gleaned through the textual analysis contributes to understandings of how academics might be navigating and negotiating the neoliberal university. In particular, we highlight the implications of precariousness in $\mathrm{HE}$, and the potential fragility of academic selves.

\section{The changed and changing English HE landscape}

The English HE system contains different types of university institutions known as (from oldest to newest): 'Ancient'; 'Nineteenth-Century'; 'Redbrick' or 'Civic'; 'Plateglass'; and 'Post-1992' universities. The majority follow a 'Traditional' university constitution, which practices a greater degree of academic freedom, individual-led scholarship, and exclusivity of intake (especially true of 'Ancient' and 'Redbrick' universities). These are contrasted against 'Post-1992' universities, which are termed 'New' and whose set-up and working practices are largely seen as more bureaucratic, more business-minded, and have intake from a wider section of the population, for example from different socio-economic backgrounds and ethnicities (Kok et al. 2010; see also Huisman and Mampaey 2016).

Long working hours, the intensification of workloads, the increase in expectation of academics to undertake greater pastoral and administrative responsibilities (Lawthom 2015), and an exponential growth in student numbers (see Silverio 2016) are common features of academia as we now know it. All these aspects culminate in academia being 'not a 9-5 job' (Sang et al. 2015, 235), though one that can constitute beneficial and productive working conditions (Siddiquee et al. 2016). At odds with this, however, is the increasing uncertainty surrounding careers in $\mathrm{HE}$, with $34 \%$ of UK academic employees working on fixed-term contracts (Loveday 2018a), and direct funding to universities being dramatically decreased in favour of increased tuition fees paid by students (mostly through 'student loans' via Student Finance England; Bolton 2019). The 'neoliberal university' is said to place 
greater interest in profit than intellectual concerns (Giroux 2002). Further, it enforces universities, academics, other staff, and their students to be positively 'on brand' to meet the 'relentless pressure to rise in ranking systems and to produce results that make them attractive for donors and businesses that want to cooperate with them' (Strenger 2011, 148). The fractious nature of the university environment has been positioned almost comedically in the title of Smyth's (2017) book: The Toxic University: Zombie Leadership, Academic Rock Stars and Neoliberal Ideology. However, there is evidence that the high-pressured nature of the neoliberal HE environment can profoundly affect the wellbeing of staff, for instance resulting in stress and burnout (see Kinman and Wray 2013; Trowler \& Knight 2010).

The increased tuition fees, which came into effect for the September 2012 intake of students, following The Browne Review, ${ }^{1}$ meant all English universities opted to charge fees at, or close to, $£ 9,000$ per annum (Browne 2010). Emerging from the increased tuition fees is the 'student consumer' (Naidoo and Williams 2015, 208), protected by the Government's consumer protection law (see Competition \& Markets Authority 2015). With the increase in fees, prospective students have become increasingly savvy and compare educational providers on the student experience, university facilities, and graduate destinations, amongst other attributes, to ensure they receive the best value for money (Williams 2013). The idea of 'we're the customer - we pay the tuition' (Delucchi and Korgen 2002,100 ) sees students demanding excellent products, exceptional customer service (Beaton 2016), and top grades, or they will want to be compensated financially (Anderson 2010). Other researchers (e.g. Bunce, Baird, and Jones 2016; Lawthom 2015) have documented the expectation from students that lecturers must be increasingly available and respond promptly to student queries. There is also greater expectation in the quality of the lectures delivered, and lecturers are tasked with designing and delivering $£ 135$ lectures $^{2}$ (see Taylor 2011).

The recent introduction by the Government of the Teaching Excellence Framework [TEF] in UK HE is related to the aforementioned increase in tuition fees, as institutions must now demonstrate they are offering students a high-quality education (Ashwin 2017). The assessment criteria used to consider teaching quality include: Encouraging student engagement; the institution valuing teaching; ensuring courses involve rigour and stretch; and providing effective student feedback (Ashwin 2017). With TEF, the UK Government aims to build a culture where teaching has equal status with research (Department for Business, Innovation \& Skills 2015). Pressures from both the Research Excellence Framework [REF] (the UK's system for assessing the excellence of research in HE institutions) and TEF, related to heavy workloads and increased administration, have contributed to stress and anxiety amongst HE lecturers (Darabi, Macaskill, and Reidy 2017). This stress and anxiety may be heightened in situations of employment uncertainty and contractual precarity.

Whilst, as noted above, temporary employment is relatively common in academia (Waaijer et al. 2017), precarious academic employment and gender have previously been discussed as going handin-hand by UK-based female academics (e.g. Crimmins 2016; Stringer et al. 2018). In this paper, we are particularly concerned with what Berg, Huijbens, and Larsen (2016) describe as the neoliberal production of anxiety in HE. Further, we explore Hall and Bowles' $(2016,33)$ description of the university as an 'anxiety machine' and consider whether the anxiety currently manifest in HE is 'inherent in the design of a system driven by improving productivity and the potential for the accumulation of capital'; that is intentional, as opposed to an unfortunate by-product of HE marketisation.

\section{Materials and methods}

In this study, we undertook a textual analysis of the four one-hour episodes comprising the series Cheat. To increase inter-rater reliability and the validity of the analysis, each episode was reviewed by all three researchers. Each episode was viewed as a unit of analysis (see also Carter et al. 2018; for a further example of the use of this analytical approach). In undertaking this analysis, we do not employ specific philosophical approaches of work and labour applied to academia (see Connell 2009; Connell and Crawford 2007; or Winn 2015), but do draw upon the neo-liberal, cultural, and feminist critiques of the aggressive marketisation of academe (see Lawthom 2015; Silverio 2016) and the 
collapse of academic autonomy and freedom of thought (Aberbach and Christensen 2018; Connell 2006) within the academy more widely. We, therefore, lens our data, through analysis, with a critical perspective on things which are inherently real in academia (academic labour; contractual precarity; imposter syndrome), which generally go unaddressed and unspoken, but are revealed through a single dramatic performance, consisting of the four episodes of ITV 1's Cheat.

We used a coding grid to describe visual data and to record verbal data verbatim, documenting each episode number and the time of key moments. We produced a coding frame with two columns, the first 'the HE landscape' and the second 'academic self'. Abiding by this coding frame did not preclude 'additional discovery-oriented work' within the episodes (Derry et al. 2010, 16), as we noted any references which we did not consider to fit in the predetermined sections in a section headed 'Any other comments?'. There was a high degree of consistency between the researchers' observations. If there were any areas of discrepancy, the episode would have been viewed by the research team collectively as a means to guard against inherent bias, and to become reflexively more aware of any assumptions.

\section{A brief note on positionality}

Given the subjective nature of analysis of any kind, but particularly that involving a topic with which the researchers are embedded, we offer a brief note on our positionalities here (see Silverio 2018 for a further discussion of positionality). The authorship team are all young (mid-late 20s) academics based at English universities, comprising of two female Senior Lecturers at different 'Post-1992' ('New') universities on permanent contracts, and one male who is employed as a Research Associate on a fixed-term contract at one 'Nineteenth-Century' university, but also holds an Honorary Research Fellowship at a different 'Nineteenth-Century' university, and an Honorary Fellowship at a 'Redbrick' university - all of which follow a 'Traditional' university model. Cheat depicts an 'Ancient' ('Traditional') university. Each of the authorship team has current or prior experience of working on fixed-term contracts and the associated precarity. It is important to reflect on our positionalities, the type of universities in which we work, and where we locate ourselves in relation to these data as we are aware that our experiences of academia will differ from that of our readers, and the dramatic depiction of Cheat may not present an accurate reflection of academia for all those who currently work in academic settings. For example, like Leah, all three authors enjoy relatively high degrees of academic freedom, which can vary dramatically across the academic landscape both in England and worldwide and is particularly unusual for early career researchers (see Vähäsantanen et al. 2020), thus setting us 'against the grain' as it were, in comparison to some of our peers. Additionally, we can further locate ourselves within these data, given that we, like Leah and her husband Adam, have written this article almost exclusively in our 'home office' settings and outside of core working hours, in what may appear a nonconformist move to challenge the knowledge-base deficit evident in this area (see also Williams 2016). By reflexively contemplating and addressing positionality when analysing these data (see Ahern 1999), it has assisted in 'bracketing-off' biases we may hold about the subject matter (Tufford and Newman 2012), thus increasing our analytical and interpretive rigour (Gearing 2004).

\section{Results}

Herein, we present the results of a textual analysis of the series of Cheat around three key thematic areas, respectively: Emotional Labour; Precarity of Fixed-Term Contracts; and Imposter Syndrome.

\section{Emotional labour}

Emotional labour refers to the management of feelings for the benefit of a successful service delivery (Constanti and Gibbs 2004). Work intensification and emotional labour among university lectures have been explored in existing research (e.g. Berry and Cassidy 2013; Constanti and Gibbs 2004; 
Ogbonna and Harris 2004) and was a theme in our analysis. For instance, in Episode 1, after a study session with students, Leah encourages students to contact her: 'with any thoughts, problems, questions'. Here Leah can be seen to be playing to student expectations that lecturers must be increasingly available outside of taught sessions (Bunce, Baird, and Jones 2016; Lawthom, 2016). Further, this supports Barrett's (2004) argument that work associated with any given set of lectures or tutorials has additional, possibly out-of-hours, work attached to it.

Whilst one of the 'perks' of an academic career could be the ability to work from home for instance for marking, preparing lectures, and writing publications; this same flexibility can hold negative discourses (see Cloonan 2004 for an unpacking of the notion of flexibility in UK HE). Throughout the series of Cheat, we see evidence of both Leah and her academic husband: Adam, taking work home with them; not just physically, but also metaphorically, in terms of worries and concerns related to their work. Scenes include Leah and Adam discussing work and students at home; Leah and Adam sitting on their sofas with their laptops out; Adam working on a grant application, and Leah with essays sprawled out over the sofa in the evening. Existing research has found academics often work from home in non-labour time, such as evenings and weekends (e.g. Cannizzo and Osbaldiston 2015). We also see that Adam and Leah have a dedicated home office (as well as offices at work). Barrett (2004) states the use of a home office further blurs the distinction between home and work. In Episode 2, we find out Leah is writing a book and has input in this from her father, a former academic (who recently retired from the same department and university where Leah now works). Interestingly, we only see Leah working on this book outside of the university setting (either at home or at her parents' home). This supports Cannizzo and Osbaldiston's $(2015,890)$ finding that pressure on academics to establish their credentials through quantifiable data, such as publications out and grant funding in 'causes notions of work/life balance to become porous'. This also links to the haunting academic holy grail of 'publish or perish' (Doyle and Michael 2015, 671).

Further, there is some evidence of Leah's social life suffering at the expense of her work. In Episode 2 we see Leah decline a lunch date with her friend, stating: 'I've got too much work on'. Existing research has explored academic work/life balance (e.g. Cannizzo and Osbaldiston 2015) and the idea that the flexibility of academia can lead to overwork and an academic being 'on call 24:7' (Barrett 2004, 99; see also Allmer 2018). Furthermore, in a discussion of overcommitment ${ }^{3}$ in UK academics, Kinman (2016) concludes excessive involvement in the job role and a reluctance to disengage from it can threaten mental health. In Cheat, we see evidence of Leah's mental health being pushed to its limit. Leah's husband, Adam, is aware that the pressure she is under has implications on their own relationship: 'can't you see you're projecting all your anxiety and stress onto this ridiculous argument'; something which has been found to be a common occurrence across the UK HE landscape (Tytherleigh et al. 2005). Further, we see Leah resorting to taking sleeping tablets because she wants: 'Sleep ... I just wanna sleep.', thus, it could be seen that Leah is potentially experiencing burnout (Kinman, Wray, and Strange 2011). Leah also visits her Doctor where an exchange of advice seeking and giving occurs:

Leah: I feel on edge all the time ... errm ... angry, yesterday I was so angry ... I'm not usually like this.

Doctor: You mentioned you were back on medication. Is that helping?

Leah: No. Well ... it's helping me to sleep, but, I-I don't know, I've only just started taking it so ...

The exchange continues with the doctor asking whether Leah had thought about couples' counselling, which she dismisses on the premise of her perception that 'Adam would never do it'. The scene ends with Leah posing her Doctor somewhat of a rhetorical question:

Leah: I guess what I'm asking you is, if the person that you love keeps telling you that you're... neurotic ... paranoid - at what point do you start to believe them? 
It is interesting that the use of the word neurotic is chosen by Leah (apparently afforded to her by her husband, although we do not see this exchange as viewers). We argue there are elements of Leah's character which do manifest as the 'neurotic academic' (Loveday 2018a, 154); that is, a figure who is governed through responses to the anxiety generated by employment uncertainty within an increasingly competitive sector (Loveday 2018b), and thereby embody the contradictions at the heart of the English HE sector. Projection of Leah as irrational and insecure throughout the series of Cheat draws attention to the fragility of academic selves (Knights and Clarke 2014).

\section{Precarity of fixed-term contracts}

In Cheat, Leah epitomises what Brechelmacher et al. $(2015,13)$ have described as 'the rocky road to tenure'. In Episode 1, Leah is approached by a male colleague, Stephan, who informs her that he would like to arrange a meeting soon for her probation appraisal:

Stephan: Nerve-wracking right? I remember that feeling.

Leah: Yeah, well I feel like I've been waiting for a permanent position for so long, I'm just really happy here.

Later in the episode, Leah is seen discussing her position with her husband, Adam, and states: 'I've worked really hard to get here'. It is worth noting that Leah appears to be of a similar age to Stephan, possibly older, and yet he talks about securing tenure as some time back. It is well-documented women take longer to secure tenure than men (see Blackmore 2014; Kandiko Howson, Coate, and de St Croix 2018).

Women in academia are reported to face many challenges to progress their careers, mainly related to gendered institutional cultures and practices (Howe-Walsh and Turnball 2016), and more specifically an 'elitist male and masculine academy' (Reay 2004, 31). Some of these challenges are explored in Cheat through Leah, including when Leah and her husband Adam are trying for children later in life. ${ }^{4}$ It transpires that Leah, in fact, does not know if she wants a child with Adam - or at all. Interestingly, King (2015), discussing female characters in horror and myth, notes older childless women are usually portrayed as bitter and resentful, but are usually seen as clever, for instance, they hold some knowledge which is used against the main protagonist in social storytelling. In Episode 3, we learn that despite the confession of her uncertainty, Leah is pregnant. King $(2015,176)$ tells that 'unwanted children' may be experienced as an 'invasion'. Yet we see evidence that not only women's, but also men's careers can be altered by childbirth (see also Sallee's 2014 discussion of tenure versus fatherhood). Adam, who has been working on a substantial grant which we hear about through the previous episodes, tells Leah (in perhaps a move which appears unrealistic): 'We got the grant ... I turned it down because I want to be there for you and the baby'.

Throughout the series, the strain related to job insecurity is evident, particularly mentioned as a consequence of Leah's actions towards student Rose. For instance, in Episode 1, Leah is advised by her mum not to pursue her concern surrounding Rose's plagiarism for fear it may impact on her chances of a tenured position: 'Sweetheart, sweetheart, you are so close to securing this post ... don't, don't rock the boat now. What's the point?'. Other literature (e.g. Wilkinson 2019) has also reflected on the fear of how negative feedback from students could halt opportunities for a permanent academic position. The reality of this comes to light in Episode 3 when we are told by Leah's colleague Stephan that discussions of making Leah's position permanent are being postponed owing to the ongoing situation with Rose:

Leah: What happens now, when will I hear about the permanent position?

Stephan: We're going to have to delay talks about your position here in light of recent events surrounding Rose Vaughn. 
This brings to light issues of social rights and protections as well as continuity of employment, which are themes documented by other scholars researching in this area (see Laparra et al. 2004; Lawthom, 2015), as well as, of course, the power students hold as consumers (Beaton 2016; Naidoo and Williams 2015) and resultantly academics' diminished agency.

\section{Imposter syndrome}

Rose: When you're on that podium where all those great people have been before you ... you can just hear yourself talking. You're asking that question over and over again.

Leah: What's that?

Rose: Am I good enough? Do I deserve to be here?

Leah: I know the answer to that question Rose. Do you?

Imposter syndrome is a term coined in 1978 by psychologists Pauline Clance and Suzanne Imes in a discussion of high achieving women. It refers to a psychological phenomenon characterised by intense feelings of intellectual fraudulence and suggests that you believe your success was down to luck and that soon your lack of ability will be exposed (Clance and Imes 1978). In Episode 1, Rose mocks Leah, implying she only secured a position at the university as her father was an established academic who had previously taught at the institution: 'Do you really think it's a coincidence that you ended up teaching at the same university as your dad?'. This idea of 'luck, chance, and happenstance' has been reported as a perception of success amongst academics in UK HE (see Loveday 2018c, 758).

Stage fright can be directly related to imposter syndrome, as it involves concerns about an individual's ability to deliver a performance convincingly (Marshall 1994) and fear of being 'outed' for one's perceived incompetence (Scott 2007a). A comprehensive analysis of how stage fright can manifest was provided by Butler $(1999,17)$ :

\footnotetext{
Stage fright is probably a version of performance anxiety and this sudden burst of fear can be totally paralyzing when it occurs, but it is specific to people who give public performances, and may occur in those who are otherwise socially confident only when they have to perform.
}

This definition is particularly pertinent when assessing the HE landscape and both stage fright and performance anxiety have been documented in previous literature concerning university staff, including lecturers' experiences and students' perceptions of stage fright (see Scott 2007b). In Episode 1, Rose tells Leah that she has noticed physical manifestations of Leah's nervousness, including a rash on her neck and the twiddling of her engagement ring: 'You get this red mark, here [points to her own neck] ... you spin your engagement ring round on your finger, take a sip of water, trying to buy yourself a few moments'. This 'nervous rash' has been documented in older literature reviewing teacher stress (see Kyriacou and Sutcliffe 1977), and more recently in the literature about women in HE (see Brabazon 2014; Wilkinson forthcoming. While lecturers seek feedback from students on their performances (e.g. through student evaluation surveys), uninvited negative feedback may be unwelcomed. In proffering this unexpected and unwanted negative feedback (regarding Leah's stage fright) - which is tinged with truth - Rose had, in effect, 'outed' Leah (see also Wilkinson's 2019 discussion of being outed by a student). This exposed Leah's vulnerabilities and placed her on the backfoot as an academic to her student, leading her to question her significance in the academic system (Strenger 2011).

\section{Discussion}

Our analysis of the depiction of a HE lecturer in England has found the character of Leah to demonstrate the potential fragility of the academic self. Whilst emotional labour is said to be both 
unrecognised and unvalued by university managers (see Barrett 2004; Saltmarsh, Sutherland-Smith, \& Randell-Moon, 2011), it clearly exists in the current HE climate with work intensification and attempts to please the student consumer by delivering a successful service (Constanti and Gibbs 2004). Through the character of Leah, we see feelings are being suppressed on the 'front stage' (lecture hall), only to manifest 'backstage' (home). The very matter-of-fact depiction of Leah's emotional labouring could reflect how emotional labour is increasingly becoming part of the work of university lecturers, as explored in existing research (see Ogbonna and Harris 2004). Heightening these emotions is the increased precariousness of academic contracts; a well-known effect of neoliberal reform within HE settings. Our analysis through the character of Leah has revealed the emotional pressure that precarity of fixed-term contracts can bring.

Related to Leah's questioning of why she has not yet secured a permanent position are pressures of perfectionism, increasing social comparisons, and a fear of failure. These are all suggested to contribute to imposter syndrome (Sakulku and Alexander 2011). Imposter syndrome has been well documented in the academy (Loveday 2018c), ranging from research studying the incidence and impact of the phenomenon (Hutchins and Rainbolt 2017; Parkman 2016), to a specific focus on teaching evaluations (Brems et al. 1994). The character of Leah highlights the importance of taking imposter syndrome seriously, considering feeling like an imposter can lead to increased levels of stress, burnout, and decreased job performance and job satisfaction over time (Whitman and Shanine 2012).

When considering what Berg, Huijbens, and Larsen (2016) describe as the neoliberal production of anxiety in $\mathrm{HE}$, the findings of our analysis suggest that in the character of Leah and the representation of English HE in Cheat, embedded in the precarity of employment; the pressure to perform and demands to be on duty all the time, is anxiety. Our analysis of the character Leah does, therefore, lend some credence to Hall and Bowles' $(2016,33)$ description of the university as an 'anxiety machine', whereby emphasis on increased productivity is reliant on anxious and overcommitted staff. One implication of this, as shown through Cheat, is the blurring of the boundaries between work and home. Whilst Cannizzo and Osbaldiston (2015) note that it is widely unknown how academics understand 'life' in relation to their occupation, it is clear from both the representations of academics in the characters of Leah and Adam that their working life spills over into their personal lives, and that the two aspects of their lives have in fact become so entwined that they are almost inseparable. Existing research has also found the effort academics must put into their jobs can engender conflict between work life and home life (Winefield, Boyd, and Winefield 2014).

\section{Conclusions}

In this paper, findings from a textual analysis of the four episodes comprising the ITV 1 psychological thriller Cheat, have been presented. In doing so, we have made a step towards contributing to the 'striking dearth of work on academic labour', as noted by Gill $(2014,12)$. Our analysis focused on one short television series and thereby the representation of one academic and of one HE institution; thus, it cannot be claimed to be an accurate illustration of the broader lived experiences of academics working in all universities in England. However, Cheat provided a rare opportunity to explore the English HE landscape and a close focus on one academic navigating and negotiating the requirements for academic tenure.

Despite the conceptualisation of students as consumers in more recent rhetoric (see Emerson and Mansvelt 2014), university lecturers do far more than deliver customer service. In particular, the analysis presented above has shed light on the emotional landscape in current English $\mathrm{HE}$ and the possible resultant fragility of academic selves. Further, this paper has drawn attention to the implications of precariousness in HE. Indeed, there were elements of the representation of the character Leah and the precarity she experienced which resonated with us as early career academics who have been, or are currently employed on, fixed-term contracts. The character of Leah thus enabled us to problematise the normalisation of precarious work in English HE institutions, 
hopefully, opening-up conversations about the impact of working conditions on early career academics at an individual level. Though the findings from this study cannot be generalised in the traditional sense, it is a first step in a much broader study of depictions of academic culture and practice. This paper, therefore, should act as a catalyst for further fruitful conversations around the high levels of emotional labour involved in 'being' a university lecturer and in 'doing' academia.

\section{Notes}

1. The Browne Review was a review to consider the future direction of higher education funding in England. It was launched in 9 November 2009 and published its findings on 12 October 2010.

2. This is an approximate calculation from Taylor (2011) based on $£ 9000$ tuition fee, divided by the average number of contact hours per week multiplied by the average number of teaching weeks in a year: i.e. $£ 9000$ Tuition Fee $\div$ (22 Teaching Weeks $\times 3$ Contact Hours per Week) $=£ 136$ per Hour Lecture, per Student.

3. Kinman (2016) draws on Siegrist's $(2001,55)$ definition of 'overcommitment' as: 'a set of attitudes, behaviours and emotions that reflect excessive striving in combination with a strong desire of being approved and esteemed'.

4. Although the age of the characters is not shared with viewers, Leah's character was played by actress Katherine Kelly, who at time of airing was 39; and Adam's character was played by Tom Goodman-Hill, who was 50.

\section{Acknowledgments}

To all academic staff on precarious short-term contracts: We understand. It will not always be this way and things will improve. United we can make academia a better place for staff and students alike. We are in this together and together we are the change yet to be seen in academia.

\section{Disclosure statement}

No potential conflict of interest was reported by the authors.

\section{Notes on contributors}

Catherine Wilkinson is a Senior Lecturer in Education at Liverpool John Moores University. Prior to this, Catherine worked as a Lecturer in Children, Young People and Families in the Faculty of Health and Social Care, Edge Hill University. Catherine also previously worked as a Postdoctoral Research Associate at Durham University in the School of Education. Catherine completed her PhD in Environmental Sciences at University of Liverpool, funded by an ESRC CASE award. Catherine works at the intersection of a range of research approaches, including: mixed methods, ethnographic and participatory research. Catherine's primary research interests are children's health experiences; young people and identity; community radio; and innovative methods. Catherine has an established reputation for making cutting-edge contributions, conceptually and methodologically, to research 'with' children and young people and uses this research to inspire teaching she delivers.

Sergio A. Silverio first trained in Psychological Sciences (Clinical \& Health Psychology) at the University of Liverpool and is an academic Psychologist with a research interest in women's mental health over the lifecourse. He has worked within various academic departments, most notably as a Research Assistant in Qualitative Methods at the University College London's Elizabeth Garrett Anderson Institute for Women's Health where he is now an Honorary Research Fellow, and now as a Research Associate in Social Science of Women's Health at the Department of Women \& Children's Health at King's College London. Most recently, he has been made an Honorary Fellow at the University of Liverpool's Department of Psychological Sciences, was elected as Fellow of the Royal Society for Public Health, and has read for a Master's in Psychological and Psychiatric Anthropology within the Division of Anthropology at Brunel University London. Having worked on various research projects, with mainly qualitative data, he has become an experienced qualitative researcher with particular expertise in in-depth interviewing on sensitive topics and inductive analytical methodologies. He regularly lectures and provides supervision on qualitative methods, methodologies, analysis, and writing as well as consulting widely on qualitative research.

Samantha Wilkinson is a Senior Lecturer in Childhood and Youth studies at Manchester Metropolitan University, UK; prior to this, she was a Lecturer in Human Geography at the same institution. Samantha holds a PhD in Human Geography, an MSc in Environmental Governance; and a BA (Hons) in Human Geography, all from The University of Manchester, UK. Her research expertise includes utilising a combination of conventional and innovative qualitative 
methods to conduct research on a range of themes, including: hair and identity; Airbnb; young people and alcohol consumption; and home care for people with dementia.

\section{ORCID}

Catherine Wilkinson (iD) http://orcid.org/0000-0002-9313-6585

Sergio A. Silverio (iD http://orcid.org/0000-0001-7177-3471

Samantha Wilkinson (iD http://orcid.org/0000-0002-1564-5472

\section{References}

Aberbach, J. D., and T. Christensen. 2018. "Academic Autonomy and Freedom under Pressure: Severely Limited, or Alive and Kicking?" Public Organization Review 18 (4): 487-506. doi:10.1007/s11115-017-0394-2.

Ahern, K. J. 1999. "Ten Tips for Reflexive Bracketing." Qualitative Health Research 9 (3): 407-411. doi:10.1177/ 104973239900900309.

Allmer, T. 2018. "Precarious, Always-on and Flexible: A Case Study of Academics as Information Workers." European Journal of Communication 33 (4): 381-395. doi:10.1177/0267323118783794.

Anderson, P. 2010. "Can You Get a Refund if University Fails to Deliver?" [online]. Accessed 20 March 2019. https://www. theguardian.com/money/2010/dec/18/refund-if-university-fails-deliver

Ashwin, P. 2017. "What Is the Teaching Excellence Framework in the United Kingdom, and Will It Work?" International Higher Education 88 (88): 10-11. doi:10.6017/ihe.2017.88.9683.

Barcan, R. 2013. Academic Life and Labour in the New University: Hope and Other Choices. Surrey: Ashgate Publishing.

Barcan, R. 2018. "Paying Dearly for Privilege: Conceptions, Experiences and Temporalities of Vocation in Academic Life." Pedagogy, Culture \& Society 26 (1): 105-121. doi:10.1080/14681366.2017.1358207.

Barcan, R. 2019. "Weighing up Futures: Experiences of Giving up an Academic Career." In Resisting Neoliberalism in Higher Education Volume II, edited by C. Manathunga and D. Bottrell, 43-64. Cham: Palgrave Macmillan.

Baron, P. 2014. "Working the Clock: The Academic Body on Neoliberal Time." Somatechnics 4 (2): 253-271. doi:10.3366/ soma.2014.0131.

Barrett, S. 2004. "Emotional Labour and the Permanent Casual Lecturer: Ideas for a Research Project." International Education Journal 4 (4): 92-101.

Beaton, F. 2016. "Who Pays the Piper? Who Calls the Tune? Implications of Policy for the Future Academic Workforce." Accessed 20 March 2019. https://www.srhe.ac.uk/conference2016/abstracts/0249.pdf

Berg, L. D., E. H. Huijbens, and H. G. Larsen. 2016. "Producing Anxiety in the Neoliberal University." The Canadian Geographer/Le Géographe Canadien 60 (2): 168-180. doi:10.1111/cag.12261.

Berry, K. E., and S. F. Cassidy. 2013. "Emotional Labour in University Lecturers: Considerations for Higher Education Institutions." Journal of Curriculum and Teaching 2 (2): 22-36. doi:10.5430/jct.v2n2p22.

Blackmore, J. 2014. "'Wasting Talent'? Gender and the Problematics of Academic Disenchantment and Disengagement with Leadership." Higher Education Research \& Development 33 (1): 86-99. doi:10.1080/07294360.2013.864616.

Bolton, P. 2019. Higher education funding in England (Briefing Paper No. 7393). London, UK: House of Commons Library.

Boxall, M. 2016. "Higher Education White Paper: The Big Changes." [online]. Accessed 27 March 2017. https://www. theguardian.com/higher-education-network/2016/may/16/higher-education-white-paper-the-big-changes

Brabazon, T. 2014. "'Maybe He's Just Better than You': Generation X Women and Higher Education." Journal of Women's Entrepreneurship and Education 3-4: 48-70.

Brechelmacher, A., E. Park, G. Ates, and D. F. Campbell. 2015. "The Rocky Road to Tenure -career Paths in Academia." In Academic Work and Careers in Europe: Trends, Challenges, Perspectives, edited by T. Fumasoli, G. Goastellec, and B. M. Kehm, 13-40. Switzerland: Springer.

Brems, C., M. R. Baldwin, L. Davis, and L. Namyniuk. 1994. "The Imposter Syndrome as Related to Teaching Evaluations and Advising Relationships of University Faculty Members." The Journal of Higher Education 65 (2): $183-193$. doi:10.2307/2943923.

Browne, J. 2010. Securing a Sustainable Future for Higher Education: An Independent Review of Higher Educational Funding and Student Finance. London: Her Majesty's Stationary Office.

Bruce, T. 2012. Universities and Constitutional Change in the UK: The Impact of Devolution on the Higher Education Sector. Oxford: H.E.P.I.

Bunce, L., A. Baird, and S. E. Jones. 2016. "The Student-as-consumer Approach in Higher Education and Its Effect on Academic Performance." Studies in Higher Education 42 (11): 1958-1978. doi:10.1080/03075079.2015.1127908.

Butler, G. 1999. Overcoming Social Anxiety and Shyness: A Self-help Guide Using Cognitive Behavioral Techniques. London, UK: Robinson.

Cannizzo, F., and N. Osbaldiston. 2015. "Academic Work/life Balance: A Brief Quantitative Analysis of the Australian Experience." Journal of Sociology 52 (4): 890-906. doi:10.1177/1440783315600803. 
Carter, B., L. Bray, P. Keating, and C. Wilkinson. 2018. "Parent-driven Campaign Videos: An Analysis of the Motivation and Affect of Videos Created by Parents of Children with Complex Healthcare Needs." Comprehensive Child and Adolescent Nursing 41 (4): 276-292. doi:10.1080/24694193.2017.1373160.

Clance, P. R., and S. A. Imes. 1978. "The Imposter Phenomenon in High Achieving Women: Dynamics and Therapeutic Intervention." Psychotherapy: Theory, Research \& Practice 15 (3): 241-247. doi:10.1037/h0086006.

Cloonan, M. 2004. "Notions of Flexibility in UK Higher Education: Core and Periphery Re-visited?" Higher Education Quarterly 58 (2/3): 176-197. doi:10.1111/j.1468-2273.2004.00267.x.

Competition \& Markets Authority. 2015. "Higher Education Undergraduate Students: Your Rights under Consumer Law." Accessed 20 March 2019. https://www.gov.uk/government/uploads/system/uploads/attachment_data/file/415732/ Undergraduate_students_-_your_rights_under_consumer_law.pdf

Connell, R. 2009. "Good Teachers on Dangerous Ground: Towards a New View of Teacher Quality and Professionalism." Critical Studies in Education 50 (3): 213-229. doi:10.1080/17508480902998421.

Connell, R. 2015a. "The Knowledge Economy and University Workers." Australian Universities' Review 57 (2): $91-95$.

Connell, R. 2015b. "Australian Universities under Neoliberal Management: The Deepening Crisis." International Higher Education 81 (81): 23-25. doi:10.6017/ihe.2015.81.8740.

Connell, R. 2019. The Good University: What Universities Actually Do and Why Its Time for Radical Change. London: Zed Books.

Connell, R., and J. Crawford. 2007. "Mapping the Intellectual Labour Process." Journal of Sociology 43 (2): $187-205$. doi:10.1177/1440783307076895.

Connell, R. W. 2006. "Core Activity: Reflexive Intellectual Workers and Cultural Crisis." Journal of Sociology 42 (1): 5-23. doi:10.1177/1440783306061350.

Constanti, P., and P. Gibbs. 2004. "Higher Education Teachers and Emotional Labour." International Journal of Educational Management 18 (4): 243-249.

Crimmins, G. 2016. "The Spaces and Places that Women Casual Academics (Often Fail To) Inhabit." Higher Education Research \& Development 35 (1): 45-57. doi:10.1080/07294360.2015.1121211.

Darabi, M., A. Macaskill, and L. Reidy. 2017. "A Qualitative Study of the UK Academic Role: Positive Features, Negative Aspects and Associated Stressors in A Mainly Teaching-focused University." Journal of Further and Higher Education 41 (4): 566-580. doi:10.1080/0309877X.2016.1159287.

Delucchi, M., and K. Korgen. 2002. "We're the Customer - We Pay the Tuition': Student Consumerism among Undergraduate Sociology Majors." Teaching Sociology 30 (1): 100-107. doi:10.2307/3211524.

Department for Business, Innovation \& Skills. 2015. "Teaching at the Heart of the System." [Online]. Accessed 20 March 2019. https://www.gov.uk/government/speeches/teaching-at-the-heart-of-the-system

Derry, S. J., R. D. Pea, B. Barron, R. A. Engle, F. Erickson, R. Goldman, R. Hall, et al. 2010. "Conducting Video Research in the Learning Sciences: Guidance on Selection, Analysis, Technology and Ethics." Journal of the Learning Sciences 19 (1): 3-53. doi:10.1080/10508400903452884.

Doyle, J., and C. Michael. 2015. "Does 'Get Visible or Vanish' Herald the End of 'Publish or Perish'?" Higher Education Research \& Development 34 (3): 671-674. doi:10.1080/07294360.2015.1025467.

Emerson, L., and J. Mansvelt. 2014. "'If They're the Customer, I'm the Meat in the Sandwich': An Exploration of Tertiary Teachers' Metaphorical Constructions of Teaching." Higher Education Research \& Development 33 (3): $469-482$. doi:10.1080/07294360.2013.841653.

Enright, E., L. Alfrey, and S. B. Rynne. 2017. "Being and Becoming an Academic in the Neoliberal University: A Necessary Conversation." Sport, Education and Society 22 (1): 1-4. doi:10.1080/13573322.2016.1259999.

Fraser, H., D. Michell, L. Beddoe, and M. Jarldorn. 2016. "Working-class Women Study Social Science Degrees: Remembering Enablers and Detractors." Higher Education Research \& Development 35 (4): 684-697. doi:10.1080/ 07294360.2015 .1137885 .

Gearing, R. E. 2004. "Bracketing in Research: A Typology." Qualitative Health Research 14 (10): 1429-1452. doi:10.1177/ 1049732304270394.

Gilbert, L., (Producer \& Director). 1983. Educating Rita [Motion picture]. UK: Columbia Pictures.

Gill, R. 2014. "Academics, Cultural Workers and Critical Labour Studies." Journal of Cultural Economy 7 (1): 12-30. doi:10.1080/17530350.2013.861763.

Giroux, H. 2002. "Neoliberalism, Corporate Culture, and the Promise of Higher Education: The University as a Democratic Public Sphere." Harvard Educational Review 72 (4): 425-464. doi:10.17763/haer.72.4.0515nr62324n71p1.

Hall, R., and K. Bowles. 2016. "Re-engineering Higher Education: The Subsumption of Academic Labour and the Exploitation of Anxiety." Workplace 28: 30-47.

Howe-Walsh, L., and S. Turnball. 2016. "Barriers to Women Leaders in Academia: Tales from Science and Technology." Studies in Higher Education 41 (3): 415-428. doi:10.1080/03075079.2014.929102.

Huisman, J., and J. Mampaey. 2016. "The Style It Takes: How Do UK Universities Communicate Their Identity through Welcome Addresses?" Higher Education Research \& Development 35 (3): 502-515. doi:10.1080/07294360.2015.1107889.

Hutchins, H.M., and H. Rainbolt. 2017. "What Triggers Imposter Phenomenon among Academic Faculty? A Critical Incident Study Exploring Antecedents, Coping, and Development Opportunities." Human Resource Development International 20 (3): 194-214. doi:10.1080/13678868.2016.1248205. 
Kandiko Howson, C. B., K. Coate, and T. de St Croix. 2018. "Midcareer Academic Women and the Prestige Economy." Higher Education Research \& Development 37 (3): 533-548. doi:10.1080/07294360.2017.1411337.

King, R. 2015. "A Regiment of Monstrous Women: Female Horror Archetypes and Life History Theory." Evolutionary Behavioral Sciences 9 (3): 170-185. doi:10.1037/ebs0000037.

Kinman, G., and S. Wray. 2013. "Higher Stress: A Survey of Stress and Well-being among Staff in Higher Education." Accessed 14 March 2019. http://www.ucu.org.uk/media/5911/Higher-stress-a-survey-of-stress-and-well-beingamong-staff-in-higher-education-Jul-13/pdf/HE_stress_report_July_2013.pdf

Kinman, G. 2016. "Effort-reward Imbalance and Overcommitment in UK Academics: Implications for Mental Health, Satisfaction and Retention." Journal of Higher Education Policy and Management 38 (5): 504-518. doi:10.1080/ 1360080X.2016.1181884.

Kinman, G., S. Wray, and C. Strange. 2011. "Emotional Labour, Burnout and Job Satisfaction in UK Teachers: The Role of Workplace Social Support." Educational Psychology: An International Journal of Experimental Psychology 31 (7): 843-856. doi:10.1080/01443410.2011.608650.

Knights, D., and C. A. Clarke. 2014. "It's a Bittersweet Symphony, This Life: Fragile Academic Selves and Insecure Identities at Work." Organization Studies 35 (3): 335-357. doi:10.1177/0170840613508396.

Kok, S.-K., A. Douglas, B. McClelland, and D. Bryde. 2010. "The Move Towards Managerialism: Perceptions of Staff in "Traditional" and "New" UK Universities." Tertiary Education and Management 16 (2): 99-113. doi:10.1080/ 13583881003756740.

Kyriacou, C., and J. Sutcliffe. 1977. "Teacher Stress: A Review." Educational Review 29 (4): 299-306. doi:10.1080/ 0013191770290407.

Laparra, M., J. C. Barbier, I. Barmon, I. Dull, C. Frade, L. Frey, R. Lindley, and K. Vogler-Ludwig. 2004. Managing Labour Market Risks in Europe: Policy Implications. Brussels. Belgium: European Commission, ESOPW Project, DG Research, V Framework Programme.

Lawthom, R. 2015. "Women In, Through, within Science: Walls, Ceilings, Communities, and Colonies." In Keynote presented at the annual conference of The British Psychological Society [BPS] Psychology of Women Section [PoWS]. Windsor, UK, July. https://www.youtube.com/watch?v=-Wm9uA73WEo

Loveday, V. 2018a. "The Neurotic Academic: Anxiety, Casualization, and Governance in the Neoliberalising University." Journal of Cultural Economy 11 (2): 154-166. doi:10.1080/17530350.2018.1426032.

Loveday, V. 2018b. "The Neurotic Academic: How Anxiety Fuels Casualised Academic Work. Impact of Social Sciences Blog." Accessed 29 March 2019. https://blogs.Ise.ac.uk/impactofsocialsciences/2018/04/17/the-neurotic-academichow-anxiety-fuels-casualised-academic-work/

Loveday, V. 2018c. "Luck, Chance, and Happenstance? Perceptions of Success and Failure Amongst Fixed-term Academic Staff in UK Higher Education." The British Journal of Sociology 69 (3): 759-775. doi:10.1111/14684446.12307.

Marshall, J. 1994. Social Phobia: From Shyness to Stage Fright. New York, USA: Basic Books.

Naidoo, R., and J. Williams. 2015. "The Neoliberal Regime in English Higher Education: Charters, Consumers and the Erosion of the Public Good." Critical Studies in Education 56 (2): 208-223. doi:10.1080/17508487.2014.939098.

Ogbonna, E., and L. C. Harris. 2004. "Work Intensification and Emotional Labour among UK University Lecturers: An Exploratory Study." Organization Studies 25 (7): 1185-1203. doi:10.1177/0170840604046315.

Parkman, A. 2016. "The Imposter Phenomenon in Higher Education: Incidence and Impact." Journal of Higher Education Theory and Practice 16 (1): 51-60.

Reay, D. 2004. "Cultural Capitalists and Academic Habitus: Classed and Gendered Labour in UK Higher Education." Women's Studies International Forum 27 (1): 31-39. doi:10.1016/j.wsif.2003.12.006.

Sakulku, J., and J. Alexander. 2011. "The Impostor Phenomenon." The Journal of Behavioral Science 6 (1): $75-97$.

Sallee, M. W. 2014. Faculty Fathers: Toward a New Ideal in the Research University. Albany, USA: State University of New York Press.

Saltmarsh, S., W. Sutherland-Smith, and H. Randell-Moon. 2011. "'Inspired and Assisted', or 'Berated and Destroyed'? Research Leadership, Management and Performativity in Troubled Times." Ethics and Education 6 (3): $293-306$. doi:10.1080/17449642.2011.632722.

Sang, K., A. Powell., R. Finkel, and J. Richards. 2015. “'Being an Academic Is Not a 9-5 Job': Long Working Hours and the 'Ideal Worker' in UK Academia." Labour and Industry 25 (3): 235-249. doi:10.1080/10301763.2015.1081723.

Scott, S. 2007a. Shyness and Society: The Illusion of Competence. Basingstoke, UK: Palgrave.

Scott, S. 2007b. "College Hats or Lecture Trousers? Stage Fright and Performance Anxiety in University Teachers." Ethnography and Education 2 (2): 191-207. doi:10.1080/17457820701350582.

Siddiquee, A., J. Sixsmith, R. Lawthom, and J. Haworth. 2016. "Paid Work, Lifework and Leisure: A Study of Wellbeing in the Context of Academic Lives in Higher Education." Leisure Studies 35 (1): 36-45. doi:10.1080/ 02614367.2014.967711.

Siegrist, J. 2001. "A Theory of Occupational Stress." In Stress in the Workplace: Past, Present and Future, edited by J. Dunham, 52-66. London, UK: Whur Publishers.

Silverio, S. A. 2016. "Penny for Your Thoughts? The Real Cost to Psychological Support in British Universities since the Increase in Tuition Fees." Psych-Talk 84: 20-22. 
Silverio, S. A. 2018. A Man in Women's Studies Research: Privileged in More than One Sense. In How do We Belong? Researcher Positionality Within Qualitative Inquiry, edited by B.C. Clift, J. Hatchard, and J. Gore, 39-48. Bath, UK: University of Bath.

Smyth, J. 2017. The Toxic University: Zombie Leadership, Academic Rock Stars and Neoliberal Ideology. London: Palgrave Macmillan.

Strenger, C. 2011. The Fear of Insignificance: Searching for Meaning in the Twenty-first Century. New York, USA: Palgrave Macmillan.

Stringer, R., D. Smith, R. Spronken-Smith, and C. Wilson. 2018. "'My Entire Career Has Been Fixed Term': Gender and Precarious Academic Employment at a New Zealand University." New Zealand Sociology 33 (2): 169-201.

Taylor, R. 2011. "The $£ 135$ Lecture - But Is It Worth It?” [online]. Accessed 20 March 2019. https://www.theguardian.com/ education/mortarboard/2011/apr/29/university-lecture-fees-worth-it

Trowler, P., and P. T. Knight. 2010. "Coming to Know in Higher Education: Theorising Faculty Entry to New Work Contexts." Higher Education Research \& Development 19 (1): 27-42. doi:10.1080/07294360050020453.

Tufford, L., and P. Newman. 2012. "Bracketing in Qualitative Research." Qualitative Social Work 11 (1): 80-96. doi:10.1177/ 1473325010368316.

Tytherleigh, M. Y., C. Webb, C. L. Cooper, and C. Ricketts. 2005. "Occupational Stress in UK Higher Education Institutions: A Comparative Study of All Staff Categories." Higher Education Research \& Development 24 (1): 41-61. doi:10.1080/ 0729436052000318569.

Vähäsantanen, K., S. Paloniemi, E. Räikkönen, and P. Hökkä. 2020. "Professional Agency in a University Context: Academic Freedom and Fetters." Teaching and Teacher Education 89: 1-12. doi:10.1016/j.tate.2019.103000.

Waaijer, C. J. F., R. Belder, H. Sonneveld, C. A. van Bochove, and I. C. M. van der Weijden. 2017. "Temporary Contracts: Effect on Job Satisfaction and Personal Lives of Recent PhD Graduates." Higher Education 74 (2): $321-339$. doi:10.1007/s10734-016-0050-8.

Whitman, M. V., and K. K. Shanine. 2012. "Revisiting the Imposter Phenomenon: How Individuals Cope with Feelings of Being in over Their Head." Research in Occupational Stress 10: 177-212.

Wilkinson, C. forthcoming. Imposter Syndrome and the Accidental Academic: An Autoethnographic Account. International Journal for Academic Development.

Wilkinson, S. 2019. "The Story of Samantha: The Teaching Performances and Inauthenticities of an Early Career Human Geography Lecturer." Higher Education Research \& Development 38 (2): 398-410. doi:10.1080/07294360.2018.1517731.

Williams, J. 2013. Consuming Higher Education: Why Learning Can't Be Bought. London, UK: Bloomsbury.

Williams, J. 2016. Academic Freedom in an Age of Conformity: Confronting the Fear of Knowledge. London, UK: Palgrave Macmillan.

Winefield, H. R., C. Boyd, and A. H. Winefield. 2014. "Work-family Conflict and Well-being in University Employees." The Journal of Psychology 148 (6): 683-697. doi:10.1080/00223980.2013.822343.

Winn, J. 2015. "Writing about Academic Labour." Workplace: A Journal for Academic Labor 25: 1-15. 